\title{
A new finding for determining the incision line in the treatment of the septate uterus: "Süha-Levent's sign"
}

\author{
Levent Yasar • Ali Süha Sönmez • Kadir Savan
}

Received: 21 January 2007 / Accepted: 28 April 2007 / Published online: 25 May 2007

(C) Springer-Verlag 2007

\begin{abstract}
In the initial hysteroscopic examination, we noticed that there was a blue line along the septum on the midline of the endometrial cavity traversing between the two tubal ostia after the injection of methylene blue. Then, we used this blue line as a guide to determine the line of incision and we incised the septum just along it. We presented two of these cases with a new finding, which we named the "Süha-Levent sign". As a result, we believe that this finding might be used as a useful marker before incising the septate uterus.
\end{abstract}

Keywords Methylene blue $\cdot$ Hysteroscopy $\cdot$ Septate uterus

\section{Introduction}

Hysteroscopic incision of the septum is the gold standard in the treatment of cases of a septate uterus [1-3]. Determination of the incision line and depth are the most important parts of the hysteroscopic septum incision. Complications (such as perforation or incomplete incision) due to incorrect incision are not rare [3]. Septum incision is performed with an incision between the two tubal ostia on the midline. The depth of incision reaches to a level at which both of the tubal ostia could be seen on the same plane. But it is an imaginary line and it is not always easy to determine the midline because of the angled optical system and intraoperative bleeding. Determining the incision line can cause

L. Yasar $(\square) \cdot$ A. S. Sönmez $\cdot$ K. Savan

Süleymaniye Dogumevi Sifahane,

Sok No 3. Eminönü,

Istanbul 80670, Turkey

e-mail: leventderya@gmail.com some confusion in the mind of a surgeon, especially one who is at the beginning of his training program.

\section{Patient no.1}

Uterine septum was diagnosed in a 23-year-old, gravida 2, abortus 2, Caucasian woman during infertility evaluation. She had a normal hormone profile and a septate uterus (Class Vb according to AFS Classification for Mullerian Duct Anomalies) on hysterosalpingography (Fig. 1a). Laparoscopy was performed to evaluate the pelvic organs and uterine shape under general anesthesia. We applied Rubin's cannula through the cervix and injected $20 \mathrm{cc}$ sterile, $0.25 \%$ of methylene blue $(250 \mathrm{mg}$ in $1,000 \mathrm{ml}$ of $0.9 \% \mathrm{Na}$ Cl) for determining tubal patency before hysteroscopic incision of the uterine septum. Methylene blue was passed to the peritoneal cavity through both tubes. When we introduced a hysteroscope into the uterus, we saw a blue line $2-3 \mathrm{~mm}$ in width between the tubal ostiae on the middle of the endometrial cavity (Fig. 2a). We made the incision just in the blue line up to the base of the uterine septum. A $3-\mathrm{cm}$ deep incision in the uterine septum was performed by a hysteroscopic monopolar resector under laparoscopic supervision (Fig. 3a). We completed the operation after the visualization of both tubal ostia on the same plane through the hysteroscope without complication. The patient was discharged on the first postoperative day.

\section{Patient no. 2}

Uterine septum (Class $\mathrm{Vb}$ according to AFS Classification for Mullerian Duct Anomalies) was diagnosed in a 32-yearold, gravida 1, abortus 1, Caucasian woman with normal 
Fig. 1a, b Hysterosalpingographic appearances of the cases. a Patient 1 . b Patient 2
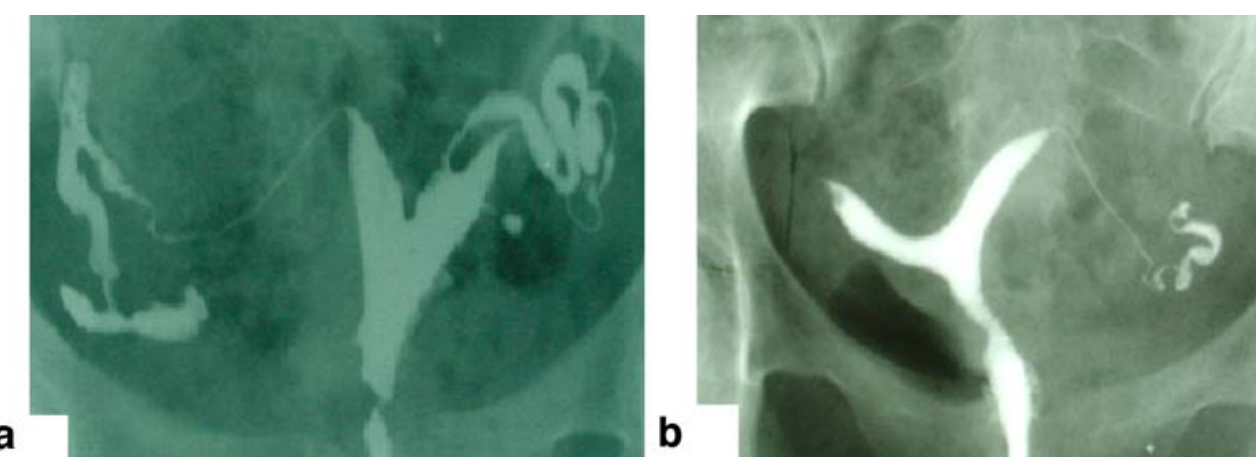

hormone profile and bilateral tubal occlusion on hysterosalpingography. She had undergone laparoscopy and hyteroscopic septum incision (Fig. 1b). Severe pelvic adhesions and occlusion at the middle portion of the right tube and left hydrosalpinx were determined by laparoscopic exploration. Laparoscopic left salpingectomy for hydrosalpinx and proximal cauterization on the right tube were performed. We saw a blue line $2-3 \mathrm{~mm}$ in width through the hysteroscope just on the midline of the endometrial cavity, the same as mentioned in first patient (Fig. 2b). A 2-cm deep septum incision was performed by a hysteroscopic monopolar resector along the blue line, under laparoscopic supervision (Fig. 3b). We completed the operation without complication and the patient was discharged the following day.

\section{Discussion}

Generally, it is easy to determine the incision line during the hysteroscopic treatment of a septate uterus. It may be problematic when the surgeons at the beginning of their training program or if another pathology or abnormality exists in the endometrial cavity. The Süha-Levent sign can help to determine the incision line. This sign was described first by Levent Yasar and was first presented by Süha Sönmez in a national congress, and then it was named as the "Süha-Levent sign." We postulated that this appearance may be due to the high-speed jet or turbulence of dye in the top or the deepest area of the uterine cavity when injected by a cannula (Rubin's cannula) through the cervical canal. The deepest region in the endometrial cavity is the zone that holds the methylene blue. The zone which holds the methylene blue is the zone where the flashing dye strikes vertically and the dye penetrates the endometrial epithelium and glands. In this way, we could make a simple hypothetical explanation for the reason why this line occured in this zone. We don't exactly know reason why the area at the top of the uterine cavity holds methylene blue. Süha-Levent's sign can also depend on cellular, histologic, or molecular abnormalities in the defective epithelium covering septum $[4,5]$. We have seen this sign even in cases with patent or occluded tubes. For now, we have only presented our observations on two cases, but soon we will present the full results of our clinical study. It is necessary to perform histologic, molecular, or clinical studies on this subject, as it may have a multifactorial etiology.

\section{Conclusion}

The findings presented in this report may shorten the training time for the hysteroscopic incision of the uterine septum. Methylene blue injection just before hysteroscopic
Fig. 2a, b Süha-Levent's sign in both cases. a Patient 1 . b Patient 2
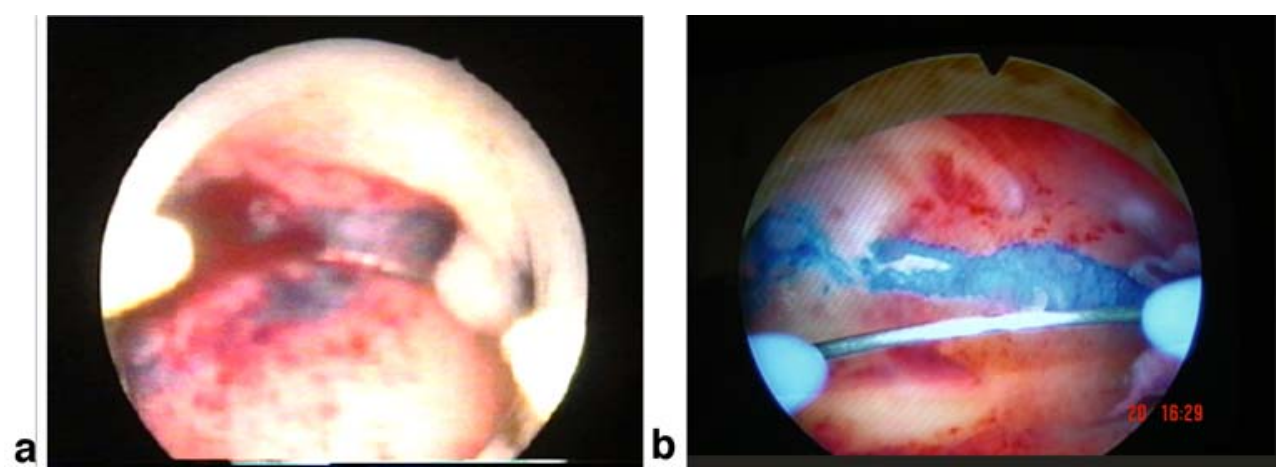
Fig. 3a, b Süha-Levent's sign and incision of the septate. a Patient 1. b Patient 2
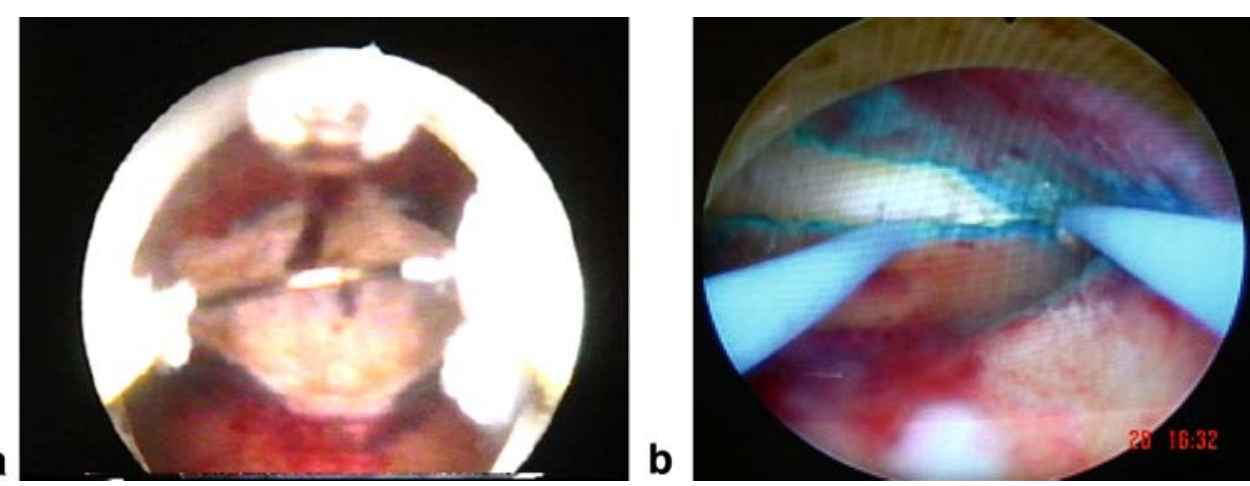

septum incision can help to identify the right incision line on the uterine septum. One can make an incision accurately on the line that holds methylene blue.

\section{References}

1. Colacurci N, De Franciscis P, Fornaro F, Fortunato N, Perino A (2002) The significance of hysteroscopic treatment of congenital uterine malformations. Reprod Biomed Online 4(Suppl 3):52-54
2. Vercellini P, Vendola N, Colombo A, Passadore C, Trespidi L, Fedele L (1993) Hysteroscopic metroplasty with resectoscope or microscissors for the correction of septate uterus. Surg Gynecol Obstet 176(5):439-442

3. Colacurci N, De Placido G, Perino A, Mencaglia L, Gubbini G (1998) Hysteroscopic metroplasty. J Am Assoc Gynecol Laparosc 5 (2):171-174

4. Zreik TG, Troiano RN, Ghoussoub RA, Olive DL, Arici A, McCarthy SM (1998) Myometrial tissue in uterine septa. J Am Assoc Gynecol Laparosc 5(2):155-160

5. Fedele L, Bianchi S, Marchini M, Franchi D, Tozzi L, Dorta M (1996) Ultrastructural aspects of endometrium in infertile women with septate uterus. Fertil Steril 65(4):750-752 